\title{
The Impact of Computerized Accounting Information Systems on the Accounts Auditing: A Case Study: Touris m Companies
}

\author{
Hany Ahmed Aly Ibrahim Khattab
}

Tourism department, Faculty of Tourism \& Hotel Management, October 6 University

\begin{abstract}
:
The accounting system is one of the most important sources of information in various companies, especially touristic ones, on which different managements depend to obtain necessary information in time. For this reason, all Companies seek to develop and update this system continuously through information technology, which provides accuracy, speed and cost reduction. As this new technology leads to a huge change in data processing and saving, there is a need to develop supervision and control procedures.

In the framework of electronic operations, it is necessary for the auditor to well understand and study the environment in which data are processed in order to facilitate the systems of accounting and internal control. To reach this target, it is required to use modern techniques and take the advantage of information technology. It is concluded that computerized and electronic systems help the auditor to reach the targets in a better way.
\end{abstract}

Key Words: Accounting - Information Systems - Tourism Companies

\section{Introduction}

World has witnessed a huge, speed, and advanced revolution in the field of information technology. This has a great effect on auditing profession. So it became necessary for this profession to cope with the new changes and keep the confidence of its benefiters by developing clear standards of auditing.

In the light of technological progress and after the revolution of information technology, accounting information systems developed as well. This led to the appearance of computerized accounting information system, in which data are operated and processed electronically (1). Accordingly, it is necessary to raise the standard of auditors to understand the various types of electronic accounting systems and their impact on Tourism Companies organizationally. The ability of auditors to detect errors and mistakes and to deal with a great amount of data in the environment of electronic accounting information systems needs to be improved as well.

As a result, electronic accounting information systems imposed a new reality upon auditors, in which entities, activities and treatments depend on computer. This change requires to replace traditional methods with modern ones that rely on the modern methods and advanced analytical tools in the auditing process. Moreover, auditors must be well aware of various systems of electronic accounting and the risks accompanying each system. They need to be armed with the tools and techniques necessary for detecting, reforming and preventing these risks, in order to achieve the goals of auditing effectively and efficiently (2).

\section{The Study problem}

The study problem can be formulated as follows:

What is the impact of electronic accounting information systems on the effectiveness of auditing process in Tourism Companies?

To simply, we will divide this problem into the following sub-questions:

1. What is the electronic accounting information system?

2. What is the conceptual framework of accounting auditing in the light of electronic accounting information systems?

3. What is the impact of electronic accounting information systems on the procedures and methods of auditing process in Tourism Companies? 
4. To what extent the proving evidences are adequate within Tourism Companies the light of electronic accounting information systems?

\section{Research hypotheses}

In the light of the study problem, we can formulate the following hypotheses:

First hypothesis: Using of electronic accounting information systems within Tourism Companies affects the methods and procedures of auditing process.

Second hypothesis: The current methods of obtaining proving evidences are inadequate for electronic accounting information systems.

\section{Importance of the study}

1. The topic of the study is an important one. So we will handle it through throwing light on the aspects of accounting process in the framework of electronic accounting information systems, and realizing to what extent the profession of auditing cope with new developments in auditing environment and the effect of this on the working environment.

2. Electronic accounting information systems have many advantages, which, if well exploited, would lead to an added value to Tourism Companies.

3. Well understanding of electronic accounting information systems is one of the most important components that help the auditor in Tourism Companies to perform his tasks effectively.

\section{Aims of study}

This study aims at:

1. knowing the impact of electronic accounting information systems on the auditor within Tourism Companies and whether they help achieving effectiveness in the accounting auditing process or not.

2. Showing the importance of the use of electronic accounting information systems to the process of accounting auditing and their contribution to the targets of the auditing process within Tourism Companies.

3. Determining the difficulties and problems the auditor faces in the light of electronic accounting information systems.

4. Clarifying the effect of electronic accounting information systems on the methods and procedures of auditing accounting process.

5. Showing how adequate are the current methods of obtaining proving evidences in the light of electronic accounting information systems.

\section{Theoretical frame work}

As an integrated framework for information flows, electronic accounting information systems are considered an important and essential tool to improve efficiency of various managements inside the company. This assures the practical and regulated execution of processes, protection of resources, preventing fraud, accuracy of accounting record, readiness of financial information, on which company can depend in adequate time. In the light of modern technological developments and appearance of electronic accounting information systems, companies, including touristic ones, have tended to use these systems to control the great amount of information and their reliability(3).

\section{Firstly: Electronic accounting information systems}

Electronic accounting information systems can be defined as "one component of administrative information system that cares of collecting, classifying, and processing financial operations, then translating them into information and communicating them to interested parties in order to rationalize their decisions(4)

Some defines electronic accounting information systems as: a part of administrative system designated to collect, classify, manipulate, analyze, and provide adequate financial information required for decision making and institution managing. Similarly, accounting information system is one component of administrative information system. But the only difference between the two systems is that the latter is 
limited to accounting information, while administrative information system includes all data and information that affect the institution activity (5).

Others define electronic accounting information systems as: "a structure or a unit used in executing the accounting task and regulating and completing the accounting cycle(6). It includes an integrated group of accounting documents, records, reports and sheets, tasks, procedures and arrangements by which financial data related to economic treatments can be collected, analyzed, recorded, summarized, and interpreted (7).

\section{Characteristics of electronic accounting information systems $(8)$}

1. High speed in operating accounting processes, which provides the users of these systems with the information necessary for decision making in time.

2. Assuring that financial data are processed according to International Fanatical Reporting Standard (IFRS), which reduces the probabilities of errors and fraud.

3. Performing inspection pre-programming tests to assure that the system requirements are applied.

4. Execution of accounting operations efficiently.

5. Classifying accounting data stored in the system from many points of view.

6. Providing more accurate results.

\section{Secondly: Auditing in the light of electronic accounting information systems}

American Accounting Association (AAA) defines auditing as "A systematic process of objectively obtaining and evaluating evidence regarding assertions about economic actions and events to ascertain the degree of correspondence between these assertions and established criteria and communicating the results to interested users".(9)

Auditing also is defined as "a process of objectively obtaining and evaluating evidence regarding management assertions about economic actions and events of a project to ascertain the degree of correspondence between these assertions and established criteria and communicating the results to interested users"(10).

However, it can be defined as: "checking the operations and limits continuously to protect the Company assets and serve the shareholders, whom it behaves on behalf. The purpose of auditing financial data is to enable auditor to present an opinion or consultation about whether these data, when preparing, were complied with all essential points of view or not. Auditing financial data is an asserting process, in which these data are representing the justice of fanatical position and the results of monetary flows"(11).

The auditing process in the light of electronic accounting information systems also defined as "a process of obtaining and evaluating evidence to determine if the use of computer contributes in meeting the auditing purposes or not, whether these purposes are related to giving opinion, as protecting Company assets and assuring data safety in fanatical reports, or the management goals, such as achieving the aims of the company effectively and using its resources efficiently(12).

From the definitions, we observe that the auditing term didn't change as a result of appearance of electronic accounting system. Moreover, there is no difference between that term in the light of complex electronic accounting systems and simple ones (14). However, there is a difference between manual accounting information systems and computerized or electronic accounting information systems. This affects the tasks of auditing in several ways, such as affecting the methods and approaches used in the auditing process. This difference can be clarified as follow (15):

a) The concept of manual accounting information systems environment

It is the traditional framework in which the ideal method of processing data is used in most, if not all, stages of the system.

b) The concept of electronic accounting information systems environment

It is the framework in which a computer is used to process data whether in the stages of inputs, processing, or outputs. I other words, the use of computers, whether owned by the company or by other 
parties and regardless of the size or type, to process the financial data transforms the accounting information system in this company into an electronic one (16).

Accordingly, in the process of auditing in the electronic system, information system (IS), information technology (IT) and information \& communication technology (ITC) are verified. However, the audit is considered a great challenge, as auditors seek to study computer operating systems and networks to be capable of executing the various stages of the auditing process (17).

This type of auditing is used to evaluate the internal control, i.e. procedures and environment of control inside the accounting information systems, and information security in all stages of this system, i.e. inputs, processing, and outputs (18).

From the above mentioned, auditing contains many elements:

a) Auditing is a systematic process:

It is executed through sequenced logical steps starting with accepting the task and discovering the environment and ending with results and reports prepared by the auditor. However, the sequenced logical steps in electronic accounting information systems differ from those in manual accounting information systems. In the latter, auditor can't observe operating processes as in the former.

b) Obtaining and evaluating evidence:

The process of obtaining and evaluating evidence is the basis of auditing. In this process, the auditor can obtain evidence through performing all the required tests and assuring the ideal execution of details. This helps to verify that the structure of internal control is working as required. Tests provide evidence that the contents of the system files show the treatments and transactions of the interested company in the right way.

c) ascertaining the correspondence between management assertions and established criteria:

The auditing process makes it possible to ascertain that management assertions correspond to accounting standards, established criteria, and accounting rules included in the laws and acts of the interested company. In this operation, there is a similarity between the electronic accounting information system and the manual one. This similarity is presented in the fact that ascertaining the correspondence between management assertions and established criteria depend on personal judgment of the auditor, who determines both the causes of violating the rules of internal control and the mistakes in the customers' accounts. However, there is a difference related to the complex procedures of auditing in electronic accounting information system as a result of the complicating internal control structure and the difficulty to verify that the files and programs presented for the auditor are genuine not false ones.

d) communicating the results to interested users:

The auditor communicates the results of auditing to the users of financial reports, whether in the electronic accounting information systems or manual ones. But in the case of electronic system, the team of auditing is regarded as users of the auditing results.

\section{Methods of auditing in electronic accounting information systems}

International Auditing Standard No. 16 includes a description of the methods of auditing using computers, various procedures that must be taken to make electronic audit reliable, and ways of execution.

The main methods of auditing using computer are(19):

1.Programs of auditing:

Programs of auditing are electronic software used by the auditor as a part of his tools and procedures of auditing. These programs helps the auditor to process the important data in the accounting system of the company. However, they can be divided into 3 classifications (20):

a. Integrated programs:

They are wide range programs designed to perform the task of processing data according to the auditor desire. Such programs are prepared by large auditing companies and offices to help the customer who prefers to use computer.

There are many advantages of the integrated programs of auditing : (21) 
- Reaching to files and searching and obtaining data easily;

- Finding solutions of mathematical problems;

- Performing logical tests;

- Providing certain reports demanded by the auditor;

- Determining the size of random sample when using statistical samples in auditing.

Examples of integrated programs of auditing are: (21) (AUDASSIST, AUDITAPE, AUDITPAK II, AUDITRONICS 32, STARTA, and SYSTEM 2190)

\section{b. Limited-purpose programs}

This kind of programs is designed to execute auditing tasks in specific conditions. So, the programs can be prepared by the auditor, the Company, or even by an outside programmer.

In some cases, auditor finds that the current programs of the company in their original, or amended, form are adequate to achieve his tasks, such as calculating salaries and revenues. Moreover, using the programs prepared by clients saves time and effort exerted to prepare specific programs that can be applied in the case of this client.

\section{c. Assisting programs}

These programs are used by the company to do the tasks of data processing such as arranging and printing data. So, these programs aren't designed for auditing purposes.

\section{Test data}

Test data are used to execute auditing procedures through entering data into the computer and comparing results to pre-established results. This method, i.e. testing processes electronically, aims at verifying the genuineness of client's programs and determining their ability to detect errors and differentiate right processes from wrong ones.

When using data test technique, it is required for the abstract processes, subjected to the test, to contain all types of errors that may occur in such a kind of processes. This enables auditor to evaluate the control procedures, which is a part of the client's program. After processing test data in the normal way, auditor must assure that test operations were removed automatically from the accounting records of the company.(22)

\section{Necessary precautions}

There are some precautions required when using auditing methods of electronic accounting information systems. The auditor, when planning for the auditing process, must take into account some of adequate manual and computerized methods. If he choose computerized methods, he will take the following factors into consideration:(23)

- The auditor's knowledge and experience of using computer;

- The degree of availability of computerized auditing methods;

- Inadequacy of manual tests operations;

- Effectiveness and efficiency;

- Timing.

\section{Practical frame work of the research:}

\section{Research community and sample:}

The community of the research is the auditors in touristic companies in Cairo and Giza governorates. The number of these auditors, whether internal or external, reached 400, representing 251 Tourism Companies in both governorates. The researcher used the approach of random sample when selecting its members. The sample of the research consisted of 200 auditors, whether internal or external. Accordingly, 200 questionnaire forms were distributed to those auditors. The Number of questionnaires delivered to the 
researcher was 188, from which 6 were excluded because of invalidity. So, the number of valid questionnaires was 182 .

\section{Tool of collecting data:}

The questionnaire was divided into two parts:

i) Personal data: such as qualification, specialization, and experiences ( table 2).

ii) other data: which included two dimensions: paragraphs to measure the impact of electronic accounting information systems on the methods and procedures of the auditing process (Table 3); and paragraphs to measure the degree of correspondence of evidence in the light of electronic accounting information systems (Table 4).

iii)

\section{Statistical tools used to analyze data}

1. Cronbach's Alpha to ascertain the reliability of research tool (87.6).

2. Percentages and frequencies: to describe the demographic characteristics of the sample members.

3. Mathematical mean: to show the increase and decrease in the response of the sample members to the questionnaire paragraphs and to show the importance of the paragraph to the sample members.

4. Standard Deviation: to measure the deviation of data from their mathematical mean.

5. T-test for the single sample: to test the hypotheses of the research.

Procedures of processing the questionnaire: Table 1.

The researcher used the five point Likert Scale to determine the degree of each paragraph, as shown in

Table (1): Five point Likert Scale

\begin{tabular}{|l|c|c|c|c|c|}
\hline Answers & $\begin{array}{c}\text { Strongly } \\
\text { agree }\end{array}$ & Agree & $\begin{array}{c}\text { Neither agree } \\
\text { nor disagree }\end{array}$ & Disagree & $\begin{array}{c}\text { Strongly } \\
\text { disagree }\end{array}$ \\
\hline Weights & 5 & 4 & 3 & 2 & 1 \\
\hline & & & & & \\
\hline
\end{tabular}


3. Characteristics of the research sample:

Table (2): Demographic Characte ris tic of the sample members

\begin{tabular}{|c|c|c|c|}
\hline \multicolumn{2}{|c|}{ Demographic Characteristics } & Frequency & Percentage \\
\hline \multirow{2}{*}{ Gender } & Male & 161 & $89.4 \%$ \\
\hline & Female & 21 & $10.6 \%$ \\
\hline \multirow{4}{*}{ Age } & Less than 30 years old & 7 & $3.8 \%$ \\
\hline & From 30 to less than 40 & 67 & $36.8 \%$ \\
\hline & From 40 to less than 50 & 68 & $37.4 \%$ \\
\hline & 50 and more & 40 & $22 \%$ \\
\hline \multirow{3}{*}{ Education } & Bachelor & 152 & $83.5 \%$ \\
\hline & Master degree & 23 & $12.6 \%$ \\
\hline & Ph. D. & 7 & $3.9 \%$ \\
\hline \multirow{3}{*}{$\begin{array}{l}\text { Experience in the } \\
\text { field of } \\
\text { accounting } \\
\text { auditing }\end{array}$} & Less than 10 years & 43 & $23.6 \%$ \\
\hline & From 10 to 15 years & 78 & $42.9 \%$ \\
\hline & More than 15 years & 61 & $33.5 \%$ \\
\hline \multicolumn{2}{|r|}{ Total } & 182 & $100 \%$ \\
\hline
\end{tabular}

Table (2) shows that most of the members of the sample are males (161, about $89 \%)$, while females are $21(10.6 \%)$.

As for age, $37 \%$ of the sample members are between 40 and 50 years old, $36.8 \%$ of are between 30 and less than 40 years old, $22 \%$ are over 50 years old, and finally $3.8 \%$ of the sample members are less than 30 years old.

It is clear that demographic characteristics have a great effect on understanding the questions of the questionnaire and answering them objectively. Education, academic specialization, and years of experience have their impact as $83.5 \%$ were bachelor degree holders, while $12.6 \%$ were master degree holders, and $3.9 \%$ were ph. D. holders.

In relation to the experience, the results show that $42.9 \%$ of the sample members have experience of 10 - 15 years, 33.5 more than 15 years, and $23.6 \%$ less than 10 years.

Years of experience enable the sample members to realize their job duties and requirements. So, there is a clear dependence on the experience factor when selecting the auditors in the touristic companies.

\section{Analyzing the data related to the answers of the sample members}

Data related to the sample members about the first dimension of the questionnaire, i.e. the impact of the accounting electronic information systems on the accounting auditing process, are shown in Table 3. 
Table (3): Analyzing the paragraphs of the first dimension of the questionnaire

\begin{tabular}{|c|c|c|c|}
\hline No. & Paragraph & $\begin{array}{l}\text { Mathematical } \\
\text { mean }\end{array}$ & $\begin{array}{l}\text { Standard } \\
\text { Deviation }\end{array}$ \\
\hline 1 & $\begin{array}{l}\text { Accounts auditing in touristic companies that use electronic } \\
\text { accounting information systems requires methods differ from } \\
\text { that applied in traditional auditing }\end{array}$ & 4.1648 & 0.68550 \\
\hline 2 & $\begin{array}{l}\text { Auditing procedures in electronic accounting information } \\
\text { systems differ from that applied in traditional ones. }\end{array}$ & 3.8571 & 0.79461 \\
\hline 3 & $\begin{array}{l}\text { Existence of specialized members in the team of auditing in the } \\
\text { Tourism Companies that use electronic accounting information } \\
\text { systems is necessary }\end{array}$ & 3.7912 & 0.77269 \\
\hline 4 & $\begin{array}{l}\text { Electronic accounting information systems help the auditor to } \\
\text { achieve the aims of auditing in a better way. }\end{array}$ & 3.6484 & 0.83267 \\
\hline 5 & $\begin{array}{l}\text { Electronic accounting information systems help in reducing } \\
\text { errors and mistakes. }\end{array}$ & 3.6538 & 0.86424 \\
\hline 6 & $\begin{array}{l}\text { Errors in Electronic accounting information systems are } \\
\text { systematic and not random }\end{array}$ & 3.8956 & 0.81089 \\
\hline 7 & $\begin{array}{l}\text { Errors in Electronic accounting information systems are related } \\
\text { to the lack of the skill of using computer }\end{array}$ & 4.1868 & 0.77120 \\
\hline 8 & $\begin{array}{l}\text { Operating electronic accounting information systems lead to a } \\
\text { high degree of accuracy and speed in processing financial data }\end{array}$ & 3.9286 & 0.83458 \\
\hline 9 & $\begin{array}{l}\text { Speed retrieving of data stored in the electronic accounting } \\
\text { information systems is possible }\end{array}$ & 3.6374 & 0.88594 \\
\hline \multirow[t]{2}{*}{10} & $\begin{array}{l}\text { The appearance of information security and safety risks in the } \\
\text { light of electronic accounting information systems affects the } \\
\text { efficiency and quality of evidences }\end{array}$ & 3.4615 & 1.04915 \\
\hline & $\begin{array}{l}\text { Auditor must assure the existence of effective control } \\
\text { procedures in the electronic accounting information systems }\end{array}$ & 4.3956 & 0.83935 \\
\hline 12 & $\begin{array}{l}\text { It is better to execute auditing programs in the light of } \\
\text { electronic accounting information systems }\end{array}$ & 3.5110 & 1.01774 \\
\hline 13 & $\begin{array}{l}\text { In the light of electronic accounting information systems, } \\
\text { information technology must be used in auditing to understand } \\
\text { internal control well }\end{array}$ & 3.9011 & 0.93496 \\
\hline 14 & $\begin{array}{l}\text { The use of electronic accounting information systems in the } \\
\text { auditing process achieves the effectiveness of auditing }\end{array}$ & 3.6813 & 0.89045 \\
\hline & Mathematical mean of the first dimension & 3.8367 & 0.60890 \\
\hline
\end{tabular}

Table 3 shows the means of the sample members' answers to the first dimension, i.e. the impact of electronic accounting information systems on the methods and procedures of auditing process. The medians varied from 3.4615 to 4.3956 ; standard deviation from 0.68550 to 1.01774 , with a general mathematical mean of the dimension of (3.8367) and a standard deviation of (0.60890). These results indicate little differences among the sample members' answers. In other word, members of the sample agreed on most paragraphs of the first dimension. 
The paragraph that states: "Auditor must assure the existence of effective control procedures in the electronic accounting information systems" came in the first place with a mean of 4.3956 and a standard deviation of 0.83935 , while the paragraph that states: "The appearance of information security and safety risks in the light of electronic accounting information systems affects the efficiency and quality of evidences" came in the second place with a mean of 3.4615 and a standard deviation of 1.04915 .

According to the results of the answers of the first dimension, the agreement of the sample members on the paragraphs of the first dimension, which is "the impact of electronic accounting information systems on the procedures and methods of auditing process", varied between (agree) and (strongly agree), while the degree of agreement on the dimension as a whole was (agree).

Data Analysis of the second dimension of the questionnaire, which is "the degree of correspondence of evidences in the light of electronic accounting information systems", is shown in Table 4.

Table (4): Analyzing the paragraphs of the second dimension of the questionnaire

\begin{tabular}{|c|l|c|c|}
\hline No. & \multicolumn{1}{|c|}{ Paragraph } & $\begin{array}{c}\text { Mathematical } \\
\text { mean }\end{array}$ & $\begin{array}{c}\text { Standard } \\
\text { De viation }\end{array}$ \\
\hline 15 & $\begin{array}{l}\text { Electronic evidences are information collected, sent, and processed } \\
\text { in the light of electronic accounting information systems }\end{array}$ & 3.8407 & 0.88692 \\
\hline 16 & $\begin{array}{l}\text { Electronic proving evidences have the following forms (picture, } \\
\text { record, sheet, document, books, and ledgers) }\end{array}$ & 3.6484 & 0.85234 \\
\hline 17 & $\begin{array}{l}\text { The rule of the auditors' dependence on electronic evidences is the } \\
\text { effectiveness of internal control at the time of discovering the } \\
\text { evidence }\end{array}$ & 3.7418 & 0.88218 \\
\hline 18 & $\begin{array}{l}\text { Impact of information technology on electronic evidence is being } \\
\text { shown according to its reliability of evidence and trust of } \\
\text { information }\end{array}$ & 3.6758 & 0.84053 \\
\hline \multicolumn{2}{|c|}{ Mathematical mean of the second dimension } & 3.7266 & 0.79913 \\
\hline
\end{tabular}

Table 3 shows the means of answers to the second dimension of the questionnaire, which is "the degree of correspondence of evidences in the light of electronic accounting information systems". The medians varied from 3.6484 to 3.8407 ; standard deviation from 0.88692 to 0.84053 , with a general mathematical mean of the dimension (3.7266) and a standard deviation of (0.79913). These results indicate little differences the sample members'. In other words, members of the sample agreed on most paragraphs of the second dimension.

The paragraph that states: "Electronic evidences are information collected, sent, and processed in the light of electronic accounting information systems" came in the first place with a mean of 3.8407 and a standard deviation of 0.88692 , while the paragraph that states: "Electronic proving evidences have the following forms (picture, record, sheet, document, books, and ledgers)" came in the second place with a mean of 3.6484 and a standard deviation of 0.85234 .

According to the results of the answers of the first dimension of the questionnaire, the agreement of the sample members on the paragraphs of the second dimension, which is "the degree of correspondence of evidences in the light of electronic accounting information systems", varied between (agree) and (strongly agree), while the degree of agreement on the dimension as a whole was (agree).

\section{Testing the hypotheses}

The first hypothesis: Using of electronic accounting information systems within Tourism Companies affects the methods and procedures of the auditing process. T-test was used to measure this hypothesis and the results are given in Table (5). 
Table (5): T-test for the first hypothesis

\begin{tabular}{|c|c|c|c|c|c|c|}
\hline $\begin{array}{c}\text { Sample } \\
\text { number }\end{array}$ & $\begin{array}{c}\text { Mathematical } \\
\text { mean }\end{array}$ & $\begin{array}{c}\text { Standard } \\
\text { deviation }\end{array}$ & $\begin{array}{c}\text { Freedom } \\
\text { degree }\end{array}$ & T values & $\begin{array}{c}\text { Probable } \\
\text { value }\end{array}$ & Conclusion \\
\hline 182 & 3.8367 & 0.60890 & 181 & 73.928 & 0.0000 & Hypothesis accepted \\
\hline$*$ T in the table $=1.660$ when indication $=0.05 ; \mathrm{T}$ in the table $=1.984$ when indication $=0.01$ and $\mathrm{F}=181$ \\
\hline
\end{tabular}

Table 5 shows that calculated $\mathrm{T}=0.9071$ is more than $\mathrm{T}$ in the table, which is 1.984 , when indication $=0.01$. Accordingly, we can accept the hypothesis that states: "Using of electronic accounting information systems within Tourism Companies affects the methods and procedures of the auditing process.

The second hypothesis: "current methods of obtaining proving evidences are inadequate for electronic accounting information systems within Tourism Companies ". T-test was used to measure this hypothesis and the results are in Table (6):

Table (6): T-test of the second hypothesis

\begin{tabular}{|c|c|c|c|c|c|c|}
\hline $\begin{array}{c}\text { Sample } \\
\text { number }\end{array}$ & $\begin{array}{c}\text { Mathematical } \\
\text { mean }\end{array}$ & $\begin{array}{c}\text { Standard } \\
\text { deviation }\end{array}$ & $\begin{array}{c}\text { Freedom } \\
\text { degree }\end{array}$ & T values & $\begin{array}{c}\text { Probable } \\
\text { value }\end{array}$ & Conclusion \\
\hline 182 & 3.7266 & 0.79913 & 181 & 54.472 & 0.0000 & Hypothesis accepted \\
\hline
\end{tabular}

$* \mathrm{~T}$ in the table $=1.660$ when indication $=0.05 ; \mathrm{T}$ in the table $=1.984$ when indication $=0.01$ and $\mathrm{F}=181$

Table 6 shows that calculated $\mathrm{T}=0.9071$ is more than $\mathrm{T}$ in the table, which is 1.984 , when indication $=0.01$. Accordingly, we can accept the hypothesis that states: "current methods of obtaining proving evidences are inadequate for electronic accounting information systems within Tourism Companies "

\section{Conclusion}

1. The use of electronic accounting information systems affects the methods and procedures of the auditing process in Tourism Companies.

2. The Current methods of obtaining proving evidences are inadequate for electronic accounting information systems within Tourism Companies

\section{Recommendations}

1. Scientific and practical qualifications are important for those who are interested in auditing financial and accounting data. They also need to be provided with advanced programs that enable them to determine the auditing plan in a way differing from that applied in non-computerized Companies. This can also help in verifying the trust and reliability of accounting information systems that are based on information technology, in a way corresponding to work procedures in the light of modern electronic techniques.

2. Managements of Tourism Companies must care about control procedures required for keeping data confidential and spreading trust in electronic tasks by the users and clients. This opens the door in front of auditors to test data and control systems easily and enables them to propose their opinions objectively.

3. Professional associations and organizations should issue standards for international and local electronic auditing, develop them to be in correspondence with electronic work environment and the new developments, and oblige those who are interested in auditing to adopt these standard.

4. New auditors must be trained and provided with a database, which can help them to improve their performance and enhance procedures of evaluating auditing risks. The suggested database should include details of the plan and the procedures required to achieve the plan effectively. 


\section{References :}

1. MWE Glautier and B Under down,(2011),Accounting Theory and Practice ,Fourth Edition ,Flb and Pitman Publishing, Great Britain , P.426 .

2. Hanno, D. M. Turner (2006). "The changing face of accounting education." Massachusetts CPA Review Vol.70(No. 1): 8-12.

3. Amen Ahmad Lutfy(2010) " Basics of accounting for auditors and chartered accountants" without , Cairo.

4. Evans, G. E. and M. G. Simkin (2009). "What best predicts computer proficiency?" Communications in the ACM Vol.32(No.11): 1322-1328.

5. Hassan Abdel -Hamid al-Attar(2000) " Suggested model for Evaluation Risks of E-Operating Environment", Commercial Research Journal, Zagazig University.

6. Burns, J. (2000). "Accounting Education for the 21st Century: The global challenges.” AAA \& Int'1 Assocc. For Accounting Education and Res. Oxford.

7. Abdul Wahab Ali(2003) " Study the effects of e-commerce", Commercial Research Journal, Alexandria University.

8. Abdul Wahab Ali(2004) " The audit in the privatization environment", Aldar Algameaya, Alexandria.

9. Issa Yassin(2003)" The principles of modern accounting", Dar Alsharq, Amman.

10. Rastogi, P. N. (2000). "Knowledge management and intellectual capital - the new virtuous reality of competitiveness." Human Systems Management 19(1):39-49.

11. Arens, Alvin A, and James K. Ioebbecke.,(2007) "Auditing: An Integrated Approach", 7rd ed., Prentice - Hall, Inc. New Jersey.

12. Dalal, Chetan, and others,(2009) "Using an Expert System in an Audit : A Case Study if Fraud Detection ", Audit Tools, IT Audit, Vol 2, May.

13. Office of Audit Services,(2014) “Internal Auditing “, MSC 3AU - New Mexico State University, Last Modified Date: October .

14. Romeny \& Steinbert,(2008) , “Accounting Information System”, Prentice Hall Business Publishing.

15. Kocharekar, R. (2001). "K-Commerce: Knowledge-based commerce architecture with convergence of e-commerce and knowledge management." Information Systems Management 18(2): 30-37.

16. The Council of the Institute of Chartered Accountants of India,(2013) "Auditing and Assurance Standard (AAS) 29 Auditing in A Computer Information Systems Environment “, January.

17. Kenneth C, Laudon, and Jane P.Laudon (2002). "Management Information System", 8 th Ed. Prentice-Hill, New Jersey .

18. Romney, Marshall and Steinbart, Paul John . (2009). Accounting information systems (11th ed.). New Jersey: Person Prentice Hall.

19. Sekaran, Uma. (2003). Research methods for business: A skill building approach (4th ed.). New York: John Wiley \& Sons Inc.

20. Knight Ridder, (2002), Accounting Standards Begin to Converge Globally, Tribune Business News; Washington; Nov. 12.

21. O.C.Ferrell and John Fraedrich, business Ethics,(2014),: Ethical Decision Making and Cases, Second Edition, Houghton Mifflin Company ,USA, P.15-87.

22. Lance McMahon,( 2015), "Corporate Accountability in Australia : Managing the Information Environment for Corporate "Journal of Business Ethics, Vol.14,issue 8, PP.673-682 . 
أثر نظم المعلومات المحاسبية الإكترونية فى مر اجعة الحسابات : دراسة تطبيقية علي شركات السياحة

الملخص

يعتبر نظام المعلومات المحاسبي مصدر ارئيسيا للمعلومات في الثركات بشكل عام وشركات السياحة بشكل خاص، حيث تعتمد عليه الإن الإدارة

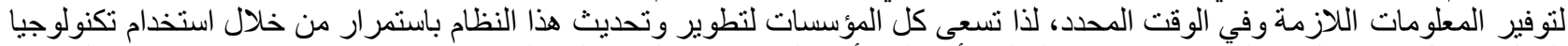

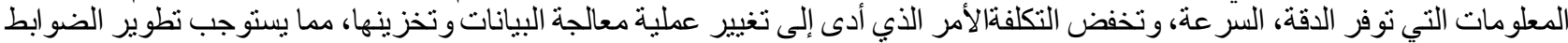

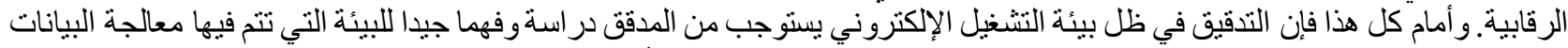

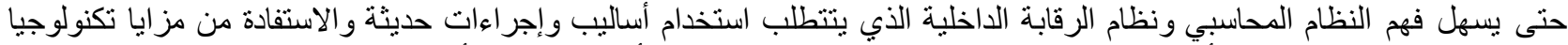
المعلومات .وخلص البحث إلى أن التشغيل الإككتروني يساعد المدقق في تحقيق الأهداف بطريقة أفضل. 